УДК 33:328.185

DOI: https://doi.org/10.32851/2708-0366/2020.3.5

Родченко С.C.

кандидат економічних наук, старший викладач кафедри фрінансово-економічної безпеки, обліку і аудиту,

Харківський національний університет міського господарства імені О.М. Бекетова ORCID: https://orcid.org/0000-0002-8611-2796

Говоруха К.В.

студентка,

Харківський національний університет міського господарства імені О.М. Бекетова

Rodchenko Svitlana

O.M. Beketov National University of Urban Economy in Kharkiv

Hovorukha Karyna

O.M. Beketov National University of Urban Economy in Kharkiv

\title{
КОРУПЦІЯ ЯК ЗАГРОЗА ЕКОНОМІЧНІЙ БЕЗПЕЦІ НАЦІОНАЛЬНОÏ ЕКОНОМІКИ
}

\section{CORRUPTION AS A THREAT TO THE ECONOMIC SECURITY OF THE NATIONAL ECONOMY}

У статті досліджено сутність поняття «корупція» через призму економічної безпеки держави. Розглянуто ї̈ вплив на економічну безпеку. Визначено, щуо основними загрозами економічній безпеці держави, які продукує корупція, є: збільшення масштабів тіньової економіки; зрощення криміналу із легальною економікою шляхом доступу до політичної влади та можливості «відмивання» брудних» грошей»; порушення конкурентних умов ринку; затримка появи ефективних приватних власників, неефективне використання бюджетних коштів; зростання ціін за рахунок включення в ціну витрат на «послуги» корумпованих чиновників, зниження довіри до держави та ї̈ можливості регулювати економічні процеси, сприяння сочуільної нерівності і збільшення розриву доходів між різними верствами населення. Запропоновано заходи спрямовані на зниження рівня корупиії в Україні та ї̈ негативного впливу на економіку.

Ключові слова: корупція, загроза, економічна безпека, тіньова економіка, індекс сприйняття корупціï. 
В статье исследована сущность понятия «коррупщия» через призму экономической безопасности государства. Рассмотрено ее влияние на экономическую безопасность. Определено, что основныли угрозами экономической безопасности государства, которые производит коррупиия, являются: увеличение масштабов теневой экономики; срашение криминала с легальной экономикой путем доступа к политической власти и возможности «отмывания «грязных» денег»; нарушение конкурентных условий рынка; задержка появления эффективных частных собственников, неэффективное использование бюджетных средств; рост ичен за счет включения в цену расходов на «услуги» коррумпированньх чиновников, снижение доверия к государству и его возможности регулировать экономические процессы, возрастание сочиального неравенства и увеличение разрыва доходов между различными слоями населения. Предложены меры, направленные на снижение уровня коррупции в Украине и ее негативного влияния на экономику.

Ключевые слова: коррупция, угроза, экономическая безопасность, теневая экономика, индекс восприятия коррупциии.

The article examines the essence of the concept of "corruption". The prevalence and scale of corruption in Ukraine have become threatening. Corruption not only undermines certain aspects of society, but also threatens the existence of the state of Ukraine. The purpose of writing this article is to study the essence of the phenomenon of "corruption" through the prism of its consequences for economic development and impact on the economic security of the state. It has been determined that corruption is a negative phenomenon that hinders the development of society, a factor that hinders economic development, as well as poses a threat to the economic security of the state and economic entities. Assessment of the dynamics of the Corruption Perceptions Index of Ukraine showed that after the Revolution of Dignity, Ukraine began a confident path to overcoming corruption. However, in 2019 its value dropped to the level of 2017. The prevalence and scale of corruption pose a real threat to the economic development of the state and its economic security. It is determined that the main threats to the economic security of the state, which are produced by corruption, are the following: increasing the scale of the shadow economy; merging crime with the legal economy through access to political power and the possibility of "laundering" dirty "money"; violation of competitive market conditions; delay in the emergence of effective private owners, inefficient use of budget funds; rising prices by including in the price the cost of "services" of corrupt officials, declining confidence in the state and its ability to regulate economic processes, promoting social inequality and increasing the income gap between different segments of the population. Measures aimed at reducing the level of corruption in Ukraine and its negative impact on the economy are proposed, namely: to create an effective and efficient system of anti-corruption justice, to actively involve business in establishing new transparent rules of government-business relations. It has been established that corruption alone will not be able to fight corruption. It is necessary to form a zero tolerance for corruption in society. index.

Key words: corruption, threat, economic security, shadow economy, corruption perception

Постановка проблеми. Мінливість умов сучасного світу створює чимало загроз економічній безпеці держави. Однією із загроз національній безпеці загалом та економічній зокрема вчені вважають корупцію як окрему внутрішню загрозу. Поширеність та масштаби корупції в Україні набули загрозливого характеру. Корупція не тільки підриває окремі сторони життя суспільства, а й загрожує існуванню держави України.

Аналіз останніх досліджень і публікацій. Проблема корупції пронизує різні сфери життя суспільства, а тому є предметом досліджень різних наукових шкіл. Корупцію досліджують юристи, психологи, соціологи, політологи та інші. Проте проведений аналіз наявних наукових праць показав, що фундаментальні економічні дослідження не відповідають гостроті цієї проблеми. Вивченню поняття «корупція» присвячено праці Л.І. Аркуші, А.В. Гайдука, О.Г. Кальмана, О.О. Мельника, О.Я. Прохоренка, I.О. Ревак, М.І. Хавронюка. Дослідження впливу корупції на економічну систему здійснювали О.І. Барановський, Л.В. Герасименко, Д. Кауфман, О.С. Коростін та інші. Дослідники у своїх працях акцентують увагу на окремих аспектах прояву корупційних дій, їх причинах та наслідках. Проте дослідженню сутності корупції, суспільних та 
індивідуальних втрат суб’єктів економіки, загроз для економічної безпеки та наслідків для економіки країни від ії існування необхідно приділити більше уваги.

Формулювання цілей статті. Метою написання статті є дослідження сутності явища корупції через призму її наслідків для розвитку економіки та впливу на економічну безпеку держави.

Виклад основного матеріалу. Корупція $є$ однозначно негативним явищем, яке здійснює вплив на різні сфери життя суспільства: соціальну, моральну, психологічну, економічну. Поширення корупції в Україні і світі визначає цю проблему як серйозну загрозу. Проведене експертами Всесвітнього економічного форуму дослідження щодо виявлення ризиків та загроз, які можуть змінити світовий уклад та викликати кризи в найближчому десятилітті, визначило корупцію як загрозу геополітичному укладу [1]. Щорічно Міжнародна організація Transparency International проводить оцінку індексу сприйняття корупції у світі. Оцінка динаміка індексу сприйняття корупції України показав, що після революції гідності Україна почала впевнений шлях до подолання корупції. Про це свідчить щорічне збільшення цього показника. Так, якщо у 2014 р. індекс прийняття корупції в Україні становив 26 балів зі 100 можливих (чим вищий бал, тим менш толерантне до корупції суспільство) до 32 балів у 2018 р. Щоправда, у 2019 р. спостерігаємо зниження індексу на 2 бали до 30 балів [2].

Зазначимо, що поняття «корупція» нині не має єдиного, універсального визначення. У науковій літературі $є$ чимало підходів до розуміння корупції. Так, Л.I. Аркуша визначає корупцію як протиправну діяльність певних осіб, спрямовану на використання свого службового та суспільного статусу для особистого збагачення, збагачення своїх родичів і прибічників, отримання інших переваг і благ усупереч інтересам суспільства [3, с. 41]. А.О. Карасевич під корупцією розуміє протиправну діяльність, яка полягає у використанні службовими особами їхніх прав і посадових можливостей для особистого збагачення; підкупність і продажність громадських і політичних діячів [4, с. 519]. Водночас, на думку Ю.С. Шемшученко, корупція - одна 3 форм зловживання владою, пов'язаного 3 підкупом посадових осіб [5]. На думку М.І. Мельника, корупція - це соціальне явище, яке охоплює всю сукупність корупційних діянь, пов'язаних із неправомірним використанням особами, уповноваженими на виконання функцій держави, наданої їм влади, службових повноважень, відповідних можливостей $з$ метою задоволення особистих інтересів чи інтересів третіх осіб, а також інших корупційних правопорушень, у тому числі тих, які створюють умови для вчинення корупційних діянь [6]. А І.В. Пиголенко визначає корупцію як багатоаспектне, багаторівневе, системно організоване соціальне явище, що органічно інтегрує в собі як економічну, юридичну, етичну, так і соціальну складові частини [7]. Погоджуючись із думкою І.Б. Висоцької, вбачаємо за доцільне згрупувати наявні визначення у дві групи - трактування «корупції» як протиправних дій та як негативного суспільного явища [8].

Чинний Закон України «Про запобігання корупції» під корупцією розуміє використання уповноваженою на виконання функцій держави або місцевого самоврядування особою наданих їй службових повноважень чи пов'язаних із ними можливостей $з$ метою одержання неправомірної вигоди або прийняття такої вигоди чи прийняття обіцянки чи пропозиції такої вигоди для себе чи інших осіб, або відповідно обіцянку чи пропозицію чи надання неправомірної вигоди уповноваженій особі або на їі вимогу іншим фізичним чи юридичним особам з метою схилити цю особу до протиправного використання наданих їй службових повноважень чи пов'язаних із ними можливостей [9].

Незалежно від підходу розуміння сутності корупції, корупція - негативне явище, яке стримує розвиток суспільства, чинник, який стримує економічний розвиток, а 
також створює загрози економічній безпеці держави та суб'єктам господарської діяльності. Економічні втрати від корупції суттєві. Прямі економічні втрати від корупції є значними. Як зазначається у доповіді $\mathrm{OOH}$, світова економіка щороку втрачає 2,6 трильйона доларів через корупцію. Це понад 5\% глобального ВВП. Щорічний обсяг хабарів у світовому масштабі становить один трильйон доларів [10]. Непрямі економічні втрати підрахувати неможливо, проте їх масштаб є значним.

Досліджуючи корупцію, насамперед необхідно виокремити ті аспекти цього явища, які несуть реальну загрозу економічній безпеці держави. До числа таких загроз належать: збільшення масштабів тіньової економіки; зрощення криміналу із легальною економікою шляхом доступу до політичної влади та можливості «відмивання» брудних» грошей»; порушення конкурентних умов ринку; затримка появи ефективних приватних власників, неефективне використання бюджетних коштів; зростання цін за рахунок включення в ціну витрат на «послуги» корумпованих чиновників, зниження довіри до держави та ії можливості регулювати економічні процеси, сприяння соціальній нерівності і збільшення розриву доходів між різними верствами населення. Розглянемо дію окреслених чинників на економічну безпеку держави.

Збільшення масштабів тіньової економіки. Корупція і тіньова економіка є взаємодоповнюваними явищами: $з$ одного боку, корупція породжує тіньову економіку i створює умови для іiї існування, з іншого - тіньова економіка є матеріальною основою існування корупції. Аналіз залежності між індексом сприйняття корупції та рівнем тіньової економіки показав наявність тісної оберненої залежності, про що свідчить значення коефіцієнта кореляції - 0,93.

Зрощення криміналу із легальною економікою шляхом доступу до політичної влади та можсливості «відмивання» брудних» грошей». Здійснення корупційних діянь має на меті незаконне збагачення. Отримані внаслідок вчинення корупційних діянь кошти легалізуються у різний спосіб.

Державна служба фінансового моніторингу України (ДСФМУ) здійснює моніторинг фінансових операцій на предмет можливого відмивання «брудних» коштів (рис. 2).

До типових способів відмивання доходів, отриманих внаслідок корупційних дій, можна віднести:

- залучення осіб, які не мають родинних зв'язків із корупціонером;

- отримання «хабара» у готівковій формі з подальшим переведення коштів у безготівкову форму;

- отримання корупційних доходів в Україні з подальшою їх легалізацією за кордоном;

- отримання спадщини (неодноразове) від осіб, не пов'язаних родинними зв'язками із корупціонером;

- придбання корпоративних прав.

Неефективне використання бюджетних коштів. Корупція здійснює подвійний негативний вплив на бюджет: по-перше, внаслідок існування тіньової економіки скорочуються податкові надходження до бюджету, по друге, бюджетні кошти використовуються неефективно, оскільки насамперед фінансуються корумповані витрати влади. Зниження індексу сприйняття корупції на одну позицію зменшує доходи держави на 1,71-2,51\% ВВП. [8]. А посилення корупції на одиницю зменшує відношення витрат на освіту та медицину до ВВП на $0,34-0,45 \%$ [13].

Зростання цін за рахунок включення в ціну витрат на «послуги» корумпованих чиновників. Корупція сприяє подорожчанню товарів. Виробники вимушені сплачувати хабарі, а понесені витрати включають у ціну, цим самим перекладаючи витрати на споживачів. Корупція не тільки підвищує вартість товарів, збільшується вартість інвестицій та інвестиційних проектів. Встановлено, що через корупцію інвестиційні проекти дорожчають на 10-20\%. 


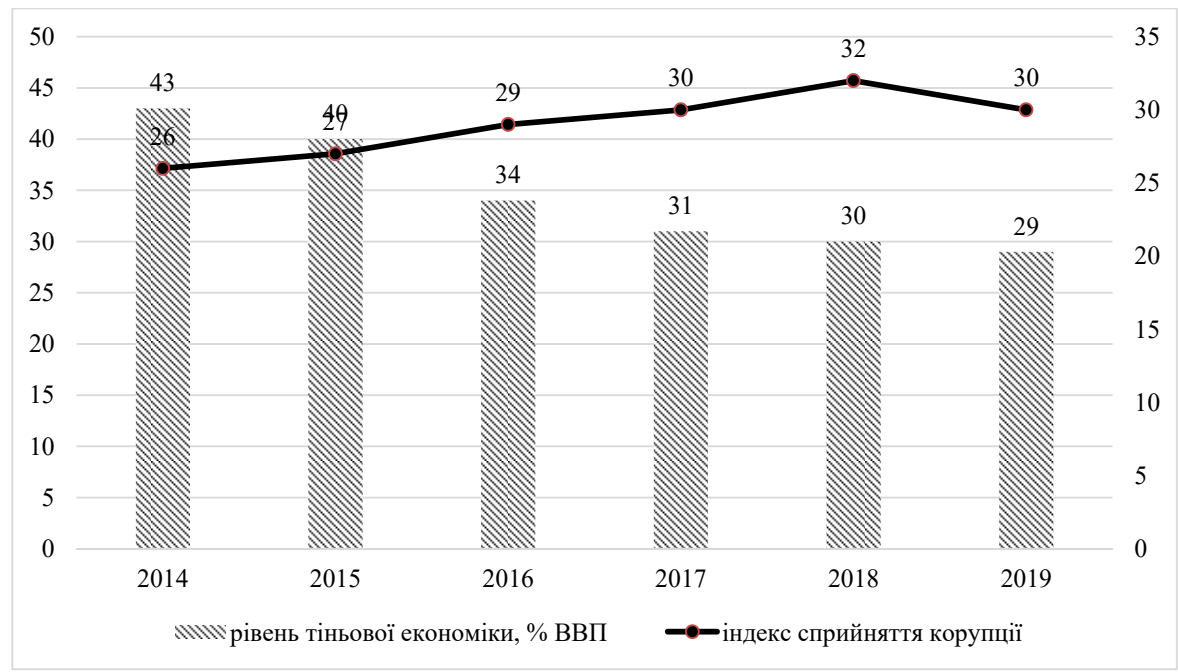

Рис. 1. Рівень тіньової економіки та індекс сприйняття корупиії в Украӥні упродовж 2014-2019 рр.

Джерело: розраховано за даними [11]

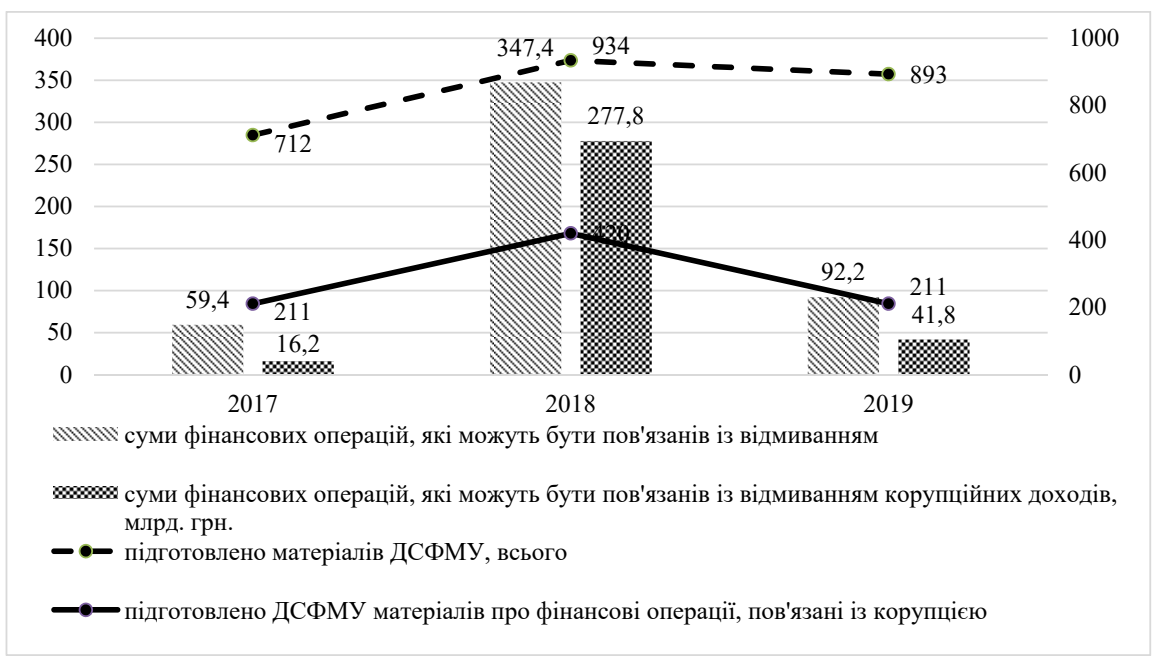

Рис. 2. Кількість підготовлених матеріалів ДСФМУ та суми фінансових операцій, пов'язаних із відмиванням «брудних» коштів в Україні упродовж 2017-2019 рр. Джерело: розраховано за даними [12]

Збільшення розриву між доходами різними верствами населення. Корупція сприяє несправедливому перерозподілу благ на користь обмеженої групи населення. Це сприяє зростанню майнової нерівності серед населення.

Окрім того, вагому частку тіньових доходів отримують представники саме високодохідних груп населення. Понад 70\% неформального доходу отримують $20 \%$ заможних домогосподарств України. За даними інших, найбільш спрощена реальна картина розподілу сукупних грошових доходів (з урахуванням валютних) серед соціальних верств 
населення нині може бути представлена так: 40\% населення країни одержує близько $10 \%$ сукупних грошових доходів (з яких близько 10\% - тіньові); $30 \%$ населення - до $30 \%$ доходів (близько третини яких знаходиться у тіні); $10 \%$ населення - близько $40 \%$ обсягів сукупних доходів, які одержує населення країни (з них близько 75\% - тіньові) [14].

Висновки. Загрозливою перепоною для економічного розвитку держави $\epsilon$ корупція. Корупція - ганебне явище, яке пронизує всі сфери суспільства: психологічну, соціальну, політичну, моральну. Поширеність та масштаби корупції несуть реальну загрозу економічному розвитку держави та її економічній безпеці. Серед основних загроз економічній безпеці, породжених корупцією, необхідно виділити такі: зростання рівня тіньової економіки, відмивання «корупційних» доходів та їх проникнення в легальну економіку, неефективне використання бюджетних коштів, зростання цін за рахунок «корупційних» витрат, зростання соціальної нерівності.

Становлення української держави без подолання корупції неможливе. Тому на сучасному етапі необхідно створити ефективну та дієву систему антикорупційного правосуддя, активно залучати бізнес до встановлення нових прозорих правил відносин суспільства влади та бізнесу. Проте одними силовими методами побороти корупцію не вдасться. Необхідно формувати в суспільстві нульову толерантність до корупції.

\section{Список використаних джерел:}

1. The Global Risks. Report 2020. Insight Report 15th Edition: 102 p. URL: www.weforum.org.

2. Індекс сприйняття корупції-2019. URL: http://cpi.ti-ukraine.org/ (дата звернення: 22.10.2020).

3. Аркуша Л.И. Выявление и расследование организованной преступной деятельности при наличии коррупционных связей. Одесса : Одесская нац. юр. академия, 2003. 207 с.

4. Карасевич А.О., Шачковська Л.С. Політологічна енциклопедія : навч. Посібник. Умань : ФОП Жовтий О.О., 2016. 768 с.

5. Юридичний словник-довідник / за ред. Ю.С. Шемшученка. Київ : Феміда, 1996. 696 с.

6. Мельник М.I. Корупція: сутність, поняття, заходи протидії : монографія. Київ : Атіка, 2001. $304 \mathrm{c}$.

7. Пиголенко I.В. Хабарництво як соціальний феномен сучасного суспільства URL://nbuv.gov.ua/portal/soc_gum/VKPI_soc/2009/ Pugolenko.pdf. (дата звернення: 22.10.2020).

8. Висоцька І.Б., Висоцький В.М. Корупція в Україні: сутність та наслідки для економіки. Науковий вісник Львівського державного університету внутрішніх справ. Серія економічна. 2017. Вип. 1. С. 37-46.

9. Про запобігання корупції: Закон України від 14.10.2014 № 1700-VII. URL: http://zakon3.rada.gov.ua/laws/show/1700-18 (дата звернення: 22.10.2020).

10. Через корупцію світова економіка щороку втрачає 2,6 трлн доларів - ООН. URL: http: https://www.radiosvoboda.org/a/news-svitova-korupcija.html (дата звернення: 22.10.2020).

11. Офіційний сайт Міністерства економічного розвитку i торгівлі України.URL: https://www.me.gov.ua (дата звернення: 22.10.2020).

12. Офіційний сайт Державної служби фінансового моніторингу України. URL: https://fiu.gov.ua/ (дата звернення: 22.10.2020).

13. Висоцька І.Б., Нагірна О.В., Силкін О.С. Економічні наслідки корупції в Україні. Причорноморські економічні студї: науковий журнал. 2019. Вип. 42. С. 182-188.

14. Нагорна А.М. Диференціація доходів населення та економічне зростання в Україні. Інфраструктура ринку. 2019. Вип. 35. С. 343-349.

\section{References:}

1. The Global Risks (2020) Insight Report 15th Edition. 102 p. Available at: www.weforum.org (accessed 22 October 2020).

2. Indeks spryiniattia koruptsii-2019 [Corruption Perceptions Index 2019]. Available at: http://cpi.ti-ukraine.org/ (accessed 22 October 2020).

3. Arkusha L.I. (2003) Vyiyavlenie i rassledovanie organizovannoy prestupnoy deyatelnosti pri nalichii korruptsionnyih svyazey [Detection and investigation of organized criminal activity in the presence of corrupt connections]. Odessa: Odesskaya nats. yur. Akademiya. (in Ukrainian) 
4. Karasevych A.O., Shachkovska L.S. (2016) Politolohichna entsyklopediia [Political Science Encyclopedia]. Uman: FOP Zhovtyi O.O. (in Ukrainian)

5. Shemshuchenko Yu. S. (ed.) (1996) Iurydychnyi slovnyk-dovidnyk [Legal dictionary-reference]. Kyiv: Femida. (in Ukrainian)

6. Melnyk M.I. (2001) Koruptsiia: sutnist, poniattia, zakhody protydii [Corruption: essence, concept, countermeasures]. Kyiv: Atika. (in Ukrainian)

7. Pyholenko I.V. Khabarnytstvo yak sotsialnyi fenomen suchasnoho suspilstva [Bribery as a social phenomenon of modern society]. Available at: http://nbuv.gov.ua/portal/soc_gum/VKPI_soc/ 2009_4/ Pugolenko.pdf (accessed 22 October 2020).

8. Vysotska I.B., Vysotskyi V.M. (2017) Koruptsiia v Ukraini: sutnist ta naslidky dlia ekonomiky. [Corruption in Ukraine: essence and consequences for the economy]. Naukovyi visnyk Lvivskoho derzhavnoho universytetu vnutrishnikh sprav. Seriia ekonomichna, vol. 1, pp. 37-46.

9. Pro zapobihannia koruptsii: Zakon Ukrainy vid від 14.10.2014 № 1700-VII. [On prevention of corruption: Law of Ukraine]. Available at: http://zakon3.rada.gov.ua/laws/show/1700-18 (accessed 22 October 2020).

10. Cherez koruptsiiu svitova ekonomika shchoroku vtrachaie 2,6 trln dolariv - OON [Due to corruption, the world economy loses $\$ 2.6$ trillion annually - the UN]. Available at: https://www.radiosvoboda.org/a/news-svitova-korupcija.html (accessed 22 October 2020).

11. Ofitsiinyi sait Ministerstva ekonomichnoho rozvytku i torhivli Ukrainy. [Official site of the Ministry of Economic Development and Trade of Ukraine]. Available at: https://www.me.gov.ua (accessed 22 October 2020).

12. Ofitsiinyi sait Derzhavnoi sluzhby finansovoho monitorynhu Ukrainy [Official site of the State Financial Monitoring Service of Ukraine]. Available at: https://fiu.gov.ua/ (accessed 22 October 2020).

13. Vysotska I.B., Nahirna O.V., Sylkin O.S. (2019) Ekonomichni naslidky koruptsii v Ukraini. [Economic consequences of corruption in Ukraine]. Prychornomorski ekonomichni studii: naukovyi zhurnal, vol. 42, pp. 182-188.

14. Nahorna A.M.(2019) Dyferentsiatsiia dokhodiv naselennia ta ekonomichne zrostannia v Ukraini [Differentiation of household incomes and economic growth in Ukraine]. Infrastruktura rynku. vol. 35, pp. 343-349. 